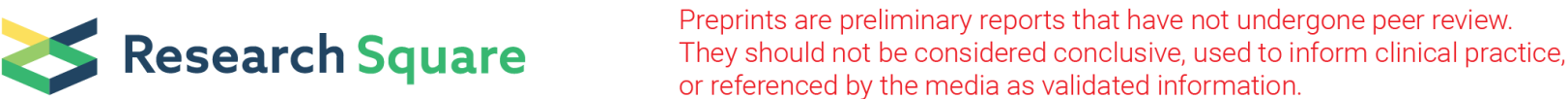

\section{Socioeconomic differentials in trends in the prevalence of hypertension and pre-hypertension and hypertension awareness, treatment, and control in rural Southwestern China}

\section{Luming Fan}

Kunming Medical University https://orcid.org/0000-0002-9852-9599

\section{Fang Wang}

Kunming Medical University

Min Zhao

Kunming Medical University

Wen-Long Cui

Kunming Medical University

Le Cai ( $\nabla$ caile002@hotmail.com )

Kunming Medical University https://orcid.org/0000-0001-7315-8077

\section{Research article}

Keywords: Hypertension, temporal trend, socioeconomic differentials, awareness, treatment, control, China

Posted Date: February 16th, 2021

DOI: https://doi.org/10.21203/rs.3.rs-132859/v2

License: (c) (i) This work is licensed under a Creative Commons Attribution 4.0 International License. Read Full License 


\section{Abstract}

Background: This study examines the socioeconomic differentials in trends in the prevalence of hypertension and pre-hypertension and hypertension awareness, treatment, and control in rural Southwestern China.

Methods: Two cross-sectional interviews and health examination surveys were administered in rural Yunnan Province, including 6,350 consenting participants in 2009 and 6,359 consenting participants in 2016 (aged $\geq 35$ years). Participant demographics, socioeconomic status (SES), and ethnicity, along with information about hypertension awareness, treatment, and control, were collected using similar questionnaires in the two surveys. The participants' blood pressure levels were also measured.

Results: From 2009 to 2016, the prevalence of hypertension substantially increased from $28.4 \%$ to $39.5 \%$ $(P<0.01)$, and awareness and control rose from 42.2 and $25.8 \%$ to $53.1(P<0.01)$ and $30.6 \%(P<0.05)$, respectively. Although people with a higher education level also had higher awareness and control rates than the lower education level ones, there were no conspicuous differences in the improvement of awareness and control between publics with different education levels over the 7 years studied. Increases were observed in both rates of awareness and control in people with a high level of income $(P<0.01)$. However, only the awareness rate increased in participants with a low level of income. Furthermore, the prevalence $(P<0.01)$ and treatment $(P<0.05)$ of hypertension were higher in the Han people than in ethnic minorities.

Conclusions: Individual SES has clear associations with trends in the prevalence, awareness, and control of hypertension. Future interventions to improve hypertension prevention and control should be tailored to address individual SES.

\section{Background}

Hypertension is a widespread and severe public health issue throughout the world. It is also a major independent, progressive hazard for chronic non-communicable diseases (NCDs), specifically for cardiovascular diseases (CVDs) with substantial economic and health losses across the globe [1]. The growing prevalence of hypertension can be observed in countries of all income levels [2]. In China, the state hypertension prevalence in people aged $\geq 18$ years was $25.2 \%$ in 2016 , a dramatical increase compared to the prevalence of $5.1 \%$ in $1959,7.7 \%$ in $1980,13.6 \%$ in 1991, and $17.6 \%$ in 2002 [3]. Prehypertension, an medium phase between normal blood pressure (BP) and hypertension, is also common in the world and varies by race and region [4]. A study by Kim has shown that individuals with prehypertension, particularly the elderly, are prone to developing hypertension [5].

Generally, the rates in awareness, treatment, and control of hypertension are meaningfully higher in developed countries than in developing ones [6, 7]. China has improved hypertension management substantially over the past years. Nevertheless, the rates in awareness, treatment and control for hypertension are remain relatively low $(28.9 \%, 35.3 \%$, and $3.4 \%$, respectively) related to those described in 
developed countries [8, 9]. Awareness and knowledge of pre-hypertension and hypertension are critical for the prevention and reduction of hypertension, particularly in rural regions where the levels of awareness and treatment are relatively lower[10].

Socioeconomic status (SES) has been found to be related to pre-hypertension and hypertension. Specifically, a lower SES is in connection with a higher risk of pre-hypertension and hypertension [11, 12], regardless of the indicators of SES that are used. However, little is known about the associations between SES and trends in prevalence, awareness, treatment, and control of hypertension all around the world, particularly in rural and ethnic minority areas in China.

China is a multi-ethnic state, in which 56 ethnicities were documented by nation. Yunnan Province was located in Southwestern China, with a population of 47.14 million in 2016. Twenty-five ethnicities dwelling in the area, and 15 are discovered only in Yunnan. The number of ethnic minorities accounts for one-third of the total population in this area. However, SES differences in trends in hypertension prevalence, awareness, treatment, and control in this particular aim crowd have not been recognized. Hence, the purpose of our study was to uncover the trends in the change in hypertension and prehypertension prevalence, and in hypertension awareness, treatment, and control and to investigate their relationships with SES indicators among Southwestern China's rural population (aged $\geq 35$ years) from 2009 to 2016.

\section{Methods}

\section{Study area and population}

In 2009 and 2016, two community-based, cross-sectional interviews and examination surveys were administered in two rural regions of Yunnan, China. In 2009, we employed a four-stage stratified random sampling method to choose the participants. In phase 1, all of the counties in Yunnan Province were classified into 2 groups, high and low, on the basis of per-capita gross domestic product (GDP). We randomly chosen one county from each of those two groups, for add up to 2 counties. In phase 2, each chosen county was also divided into 3 categories based on per-capita GDP: advantaged, average, or disadvantaged. From each of these 3 categories, one township was randomly chosen, for 6 townships in total. In phase 3 , three villages were selected by probability proportional to size (PPS) method from each township. In phase 4 and ending, from the administration in each chosen village, a residents' list aged 35 years and over was procured. Then, a simple random sampling method was employed to choose eligible persons from each chosen village. In 2016, we employed a uniform four-stage stratified random sampling technique to enable us to choose participants from the two rural regions.

\section{Data Collection And Measurement}

Similar pre-tested questionnaires were employed to assemble data from participants in the two surveys. Both in 2009 and 2016, face-to-face interviews were conducted to each consenting participant by trained interviewers. Information about participants' demographic characteristics (sex, age, ethnicity, education, 
and annual household income), diagnosis, treatment, and control of hypertension were converged. The measured BP was documented accompanied by those from the questionnaire.

BP was measured by trained interviewers using standardized mercury sphygmomanometers in 2009 and 2016, and taken from the individuals' right arm after they rested for as a minimum 5 minutes in the sitting situation and had not eaten, smoked, or exercised. Three successive BP measurements were obtained following American Heart Association (AHA) recommendations [13]. In our study, we took the mean BP of three readings. To sustain the accuracy of BP results taken by mercury sphygmomanometer, an oscillometer device was used once a week.

\section{Ethics Approval}

The Ethics Committee at Kunming Medical University authorized our study ahead of the start of the research.

\section{Definition}

Based on recommendations in the eighth Report of the Joint National Committee on the Prevention, Detection, Evaluation, and Treatment of High Blood Pressure (JNC 8) [14], pre-hypertension was defined in our study as a systolic blood pressure (SBP) of 120-139 mmHg, and/or diastolic blood pressure (DBP) of $80-89 \mathrm{mmHg}$. Hypertension was established when a person who has a mean SBP $\geq 140 \mathrm{mmHg}$, DBP $\geq 90 \mathrm{mmHg}$, and/or currently being on antihypertensive therapy. A former diagnosis of hypertension by a qualified medical institution was also viewed hypertension in our study.

Among individuals with hypertension, awareness was established in our study when an individual had reported a former hypertension diagnosis in a health facility. Treatment was established when antihypertensive therapy in the last 14 days was reported by participants. Moreover, control was established when a person who has a mean SBP $<140 \mathrm{mmHg}$ and $\mathrm{DBP}<90 \mathrm{mmHg}$ posttreatment.

Ethnicity was derived from China's 56 state-recognized ethnicities, and was then classified into two groups in our study: Han Chinese or ethnic minority. Illiterate was defined as a person who has no capability to read with grasp or to write simple sentences. The level of education was then divided into two sets: illiterate and primary (grades 1-6) or higher. Approximate yearly household income was separated into two classifications (low and high). Low referred to an approximate yearly household income $<\$ 945$, and high referred to a yearly household income $\geq \$ 945$.

\section{Statistical analysis}

We employed SPSS 22.0 software to analyze all data double-entered into an EpiData 3.1. Descriptive analysis methods and the chi-squared test and t-test were computed in this study. The mean values of SBP and DBP were stated as the mean \pm standard deviation $( \pm s)$. Counts and percentages were employed to express categorical variables in the study. A chi-squared test was applied to make a comparison on categorical variables between survey years and genders, and the t-test was analyzed 
continuous variables. We have adjusted the prevalence of hypertension and pre-hypertension, the rates in awareness, treatment, and control of hypertension, with age using a direct standardization technique for the 2010 population aged 35 years and over in China. All of the statistical significance determinations were grounded in two-tailed $P$ values of $<0.05$ in the study.

\section{Results}

In 2009 and 2016, a total of 6,600 people aged $\geq 35$ years were invited in two surveys, of which 6,350 in 2009 and 6,359 in 2016 agreed to participate, yielding a total response rate of $96.2 \%$ and $96.3 \%$, respectively.

Table 1 indicates the general features of the participants. Among the study participants in $2009,48.2 \%$ were male and $51.8 \%$ were female. In $2016,49.4 \%$ were male and $50.6 \%$ were female. There were no valid changes in proportion of males, mean age, and proportion of people with a low approximate yearly household income between the two survey years $(P>0.05)$. Nevertheless, the rate of illiteracy for females shortened from $50.9 \%$ in 2009 to $38.7 \%$ in $2016(P<0.01)$. Females had a higher illiteracy rate and a higher low approximate yearly household income rate than males both in 2009 and $2016(P<0.05)$. Moreover, males had a higher mean SBP and DBP than females in the two survey years $(P<0.05)$. 
Table 1

General characteristics of the study population by survey year

\begin{tabular}{|c|c|c|c|c|c|c|}
\hline \multirow[t]{4}{*}{ Characteristics } & \multicolumn{6}{|c|}{ Survey year } \\
\hline & \multicolumn{3}{|l|}{2009} & \multicolumn{3}{|l|}{2016} \\
\hline & Male & Female & All & Male & Female & All \\
\hline & $\begin{array}{l}(n= \\
3067)\end{array}$ & $\begin{array}{l}(n= \\
3283)\end{array}$ & $\begin{array}{l}(n= \\
6350)\end{array}$ & $\begin{array}{l}(n= \\
3143)\end{array}$ & $\begin{array}{l}(n= \\
3216)\end{array}$ & $\begin{array}{l}(n= \\
6359)\end{array}$ \\
\hline \multicolumn{7}{|l|}{ Age } \\
\hline $35-44$ years & $\begin{array}{l}712 \\
(23.2)\end{array}$ & $\begin{array}{l}761 \\
(23.2)\end{array}$ & $\begin{array}{l}1473 \\
(23.2)\end{array}$ & $\begin{array}{l}737 \\
(23.4)\end{array}$ & $\begin{array}{l}714 \\
(22.2)\end{array}$ & $\begin{array}{l}1451 \\
(22.8)\end{array}$ \\
\hline $45-54$ years & $\begin{array}{l}764 \\
(24.9)\end{array}$ & $\begin{array}{l}813 \\
(24.8)\end{array}$ & $\begin{array}{l}1577 \\
(24.8)\end{array}$ & $\begin{array}{l}830 \\
(26.4)\end{array}$ & $\begin{array}{l}895 \\
(27.8)\end{array}$ & $\begin{array}{l}1725 \\
(27.1)\end{array}$ \\
\hline $55-64$ years & $\begin{array}{l}780 \\
(25.4)\end{array}$ & $\begin{array}{l}838 \\
(25.5)\end{array}$ & $\begin{array}{l}1618 \\
(25.5)\end{array}$ & $\begin{array}{l}740 \\
(23.5)\end{array}$ & $\begin{array}{l}839 \\
(26.1)\end{array}$ & $\begin{array}{l}1579 \\
(24.8)\end{array}$ \\
\hline$\geq 65$ years & $\begin{array}{l}811 \\
(26.4)\end{array}$ & $\begin{array}{l}871 \\
(26.5)\end{array}$ & $\begin{array}{l}1682 \\
(26.5)\end{array}$ & $\begin{array}{l}836 \\
(26.6)\end{array}$ & $\begin{array}{l}768 \\
(23.9)\end{array}$ & $\begin{array}{l}1604 \\
(25.2)\end{array}$ \\
\hline \multicolumn{7}{|l|}{$\begin{array}{l}\text { Approximate yearly household } \\
\text { income (\%) }\end{array}$} \\
\hline Low & $\begin{array}{l}1230 \\
(40.1)\end{array}$ & $\begin{array}{l}1768 \\
(53.9)^{*}\end{array}$ & $\begin{array}{l}2998 \\
(47.2)\end{array}$ & $\begin{array}{l}1264 \\
(40.2)\end{array}$ & $\begin{array}{l}1614 \\
(50.2)^{*}\end{array}$ & $\begin{array}{l}2878 \\
(45.3)\end{array}$ \\
\hline High & $\begin{array}{l}1837 \\
(59.9)\end{array}$ & $\begin{array}{l}1515 \\
(46.1)\end{array}$ & $\begin{array}{l}3352 \\
(52.8)\end{array}$ & $\begin{array}{l}1879 \\
(59.8)\end{array}$ & $\begin{array}{l}1602 \\
(49.8)\end{array}$ & $\begin{array}{l}3481 \\
(54.7)\end{array}$ \\
\hline \multicolumn{7}{|l|}{ Level of education (\%) } \\
\hline Illiterate & $\begin{array}{l}740 \\
(24.1)\end{array}$ & $\begin{array}{l}1671 \\
(50.9) \star \star\end{array}$ & $\begin{array}{l}2411 \\
(38.0)\end{array}$ & $\begin{array}{l}856 \\
(27.2)\end{array}$ & $\begin{array}{l}1244 \\
(38.7) \star \star\end{array}$ & $\begin{array}{l}2100 \\
(33.0)\end{array}$ \\
\hline Primary (grade 1-6) or higher & $\begin{array}{l}2327 \\
(75.9)\end{array}$ & $\begin{array}{l}1612 \\
(49.1)\end{array}$ & $\begin{array}{l}3939 \\
(62.0)\end{array}$ & $\begin{array}{l}2287 \\
(72.8)\end{array}$ & $\begin{array}{l}1972 \\
(61.3)\end{array}$ & $\begin{array}{l}4259 \\
(67.0)\end{array}$ \\
\hline Systolic BP (mmHg) & $131^{\star} \pm 23$ & $126 \pm 22$ & $\begin{array}{l}130 \pm \\
22\end{array}$ & $129 * \pm 21$ & $127 \pm 22$ & $\begin{array}{l}128 \pm \\
22\end{array}$ \\
\hline Diastolic BP (mmHg) & $84^{\star} \pm 13$ & $80 \pm 12$ & $83 \pm 13$ & $82 * \pm 13$ & $80 \pm 13$ & $81 \pm 13$ \\
\hline
\end{tabular}

Table 2 presents the prevalence of pre-hypertension and hypertension in two survey years and SES in rural Yunnan. Over the 7 years studied, from 2009 to 2016, although the prevalence of pre-hypertension did not differ, the hypertension prevalence boosted from 28.4 to $39.5 \%(P<0.01)$, and among the subcategories, the increasing rates existed in sex, ethnicity, level of education, and approximate yearly 
household income. The prevalence of hypertension in males and in females increased from $27.6 \%$ and $28.8-39.5 \%$ and $39.8 \%$, respectively $(P<0.01)$, and in the Han majority population, it rose from $27.9-$ $40.3 \%(P<0.01)$. Moreover, in the illiterate population, it increased from $26.5-54.7 \%(P<0.01)$, and in participants with a low approximate yearly household income, it increased from $28.5-48.6 \%(P<0.01)$. In both 2009 and 2016, the prevalence of pre-hypertension was higher in male participants than in female individuals $(P<0.01)$. In 2016 , the hypertension prevalence was higher in Han majority population than in ethnicity minority population $(P<0.01)$, as well as in illiterate population than in their counterparts $(P<$ $0.01)$. Moreover, the hypertension prevalence was higher in individuals with a low approximate yearly household income than in participants with a high approximate yearly household income $(P<0.01)$. 
Table 2

Age-standardized prevalence of pre-hypertension and hypertension by survey year and socioeconomic status in rural Yunnan Province, China

\begin{tabular}{|c|c|c|c|c|}
\hline \multirow[t]{2}{*}{ Characteristics } & \multicolumn{2}{|l|}{2009} & \multicolumn{2}{|l|}{2016} \\
\hline & $\begin{array}{l}\text { Pre- } \\
\text { hypertension } \\
\text { n (\%) }\end{array}$ & $\begin{array}{l}\text { Hypertension } \\
\text { n (\%) }\end{array}$ & $\begin{array}{l}\text { Pre- } \\
\text { hypertension } \\
\text { n (\%) }\end{array}$ & $\begin{array}{l}\text { Hypertension } \\
\text { n (\%) }\end{array}$ \\
\hline \multicolumn{5}{|l|}{ Sex } \\
\hline Male & $1569(52.1)$ & $816(27.6)$ & $1676(53.5)$ & $\begin{array}{l}1242 \\
(39.5)^{\star \star}\end{array}$ \\
\hline Female & $1444(43.7)^{\star \star}$ & $975(28.8)$ & $\begin{array}{l}1504 \\
(46.4)^{\star \star}\end{array}$ & $\begin{array}{l}1280 \\
(39.8)^{\star \star}\end{array}$ \\
\hline \multicolumn{5}{|l|}{ Age } \\
\hline $35-44$ years & $663(45.2)$ & $170(11.7)$ & $705(48.2)$ & $288(19.5)$ \\
\hline $45-54$ years & $733(46.4)$ & $408(25.3)$ & $862(49.7)$ & $699(34.2)$ \\
\hline $55-64$ years & $776(47.7)$ & $530(31.9)$ & $795(50.1)$ & $745(40.8)$ \\
\hline$\geq 65$ years & $841(50.3)^{\star \star}$ & $683(40.8)^{\star \star}$ & $818(51.6)^{\star}$ & 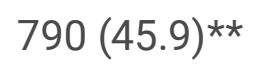 \\
\hline \multicolumn{5}{|l|}{ Ethnicity } \\
\hline Han & $2796(47.3)$ & $1660(27.9)$ & $3003(48.6)$ & $\begin{array}{l}2417 \\
(40.3)^{\star \star}\end{array}$ \\
\hline Minority & $217(46.4)$ & $131(28.3)$ & $177(48.3)$ & $105(27.2)^{\star \star}$ \\
\hline \multicolumn{5}{|l|}{ Level of education } \\
\hline Illiterate & $1073(46.8)$ & $649(26.5)$ & $1053(50.3)$ & $\begin{array}{l}1145 \\
(54.7)^{\star \star}\end{array}$ \\
\hline Primary (grade 1-6) or higher & $1940(47.7)$ & $1142(29.6)$ & $2127(49.7)$ & $\begin{array}{l}1377 \\
(32.0) \star \star\end{array}$ \\
\hline \multicolumn{5}{|l|}{$\begin{array}{l}\text { Approximate yearly household } \\
\text { income }\end{array}$} \\
\hline Low & $1367(46.9)$ & $861(28.5)$ & $1422(49.8)$ & $\begin{array}{l}1406 \\
(48.6)^{\star \star}\end{array}$ \\
\hline High & $1646(47.8)$ & $930(27.8)$ & $1758(50.1)$ & $\begin{array}{l}1116 \\
(32.4)^{\star \star}\end{array}$ \\
\hline All & $3013(47.2)$ & $1791(28.4)$ & $3180(50.0)$ & $\begin{array}{l}2522 \\
(39.5)^{\star \star}\end{array}$ \\
\hline
\end{tabular}


Table 3 shows the hypertension awareness, treatment, and control in two study years and SES in rural areas of Yunnan, China. The hypertension awareness increased from $42.2-53.1 \%(P<0.01)$, and control rose from $25.8-30.6 \%(P<0.05)$ over the 7 years studied. We found the trends of increase both in males and females, however, only observed in Han majority population and in people with a high level of income. Additionally, the awareness of hypertension also increased in those behind a low level of income. Although the hypertension awareness and control were higher in people who have a higher position in education level than in their counterparts, the improvement in awareness and control did not differ between groups of different education levels over the seven years studied. Further, there was no noteworthy change in treatment among the subcategories layered by sex, education, and income between in 2009 and in $2016(P>0.05)$. In both 2009 and 2016, the hypertension awareness and control were higher in females than in males, and the ethnicity minority population had comparatively lower treatment rates than the Han people $(P<0.05)$. 
Table 3

Age-standardized awareness, treatment, and control of hypertension by survey year and socioeconomic status in rural Yunnan Province, China

\begin{tabular}{|c|c|c|c|c|c|c|}
\hline \multirow[t]{2}{*}{ Characteristic } & \multicolumn{3}{|l|}{2009} & \multicolumn{3}{|l|}{2016} \\
\hline & $\begin{array}{l}\text { Awareness } \\
\text { of } \\
\text { condition } \\
\mathrm{n}(\%)\end{array}$ & $\begin{array}{l}\text { Under } \\
\text { treatment } \\
\mathrm{n}(\%)\end{array}$ & $\begin{array}{l}\text { Condition } \\
\text { controlled } \\
\mathrm{n}(\%)\end{array}$ & $\begin{array}{l}\text { Awareness } \\
\text { of } \\
\text { condition } \\
\mathrm{n}(\%)\end{array}$ & $\begin{array}{l}\text { Under } \\
\text { treatment } \\
\mathrm{n}(\%)\end{array}$ & $\begin{array}{l}\text { Condition } \\
\text { controlled } \\
\mathrm{n}(\%)\end{array}$ \\
\hline \multicolumn{7}{|l|}{ Sex } \\
\hline Male & 304 (37.3) & $\begin{array}{l}273 \\
(74.2)\end{array}$ & 79 (21.5) & $\begin{array}{l}619 \\
(49.8)^{\star \star}\end{array}$ & $\begin{array}{l}443 \\
(73.6)\end{array}$ & $\begin{array}{l}182 \\
(29.4)^{\star \star}\end{array}$ \\
\hline Female & $\begin{array}{l}452 \\
(46.4)^{\star \star}\end{array}$ & $\begin{array}{l}444 \\
(79.0)\end{array}$ & $\begin{array}{l}161 \\
(28.6)^{\star}\end{array}$ & $\begin{array}{l}720 \\
(56.3)^{\star \star}\end{array}$ & $\begin{array}{l}571 \\
(77.3)\end{array}$ & $\begin{array}{l}228 \\
(31.7)^{\star}\end{array}$ \\
\hline \multicolumn{7}{|l|}{ Age } \\
\hline $35-44$ years & $35(20.6)$ & $27(60.0)$ & $16(35.6)$ & $84(29.2)$ & $73(70.0)$ & $25(29.8)$ \\
\hline $45-54$ years & $141(34.6)$ & $\begin{array}{l}128 \\
(73.6)\end{array}$ & $43(25.7)$ & $276(46.1)$ & $\begin{array}{l}199 \\
(72.1)\end{array}$ & $85(30.8)$ \\
\hline $55-64$ years & 239 (45.1) & $\begin{array}{l}222 \\
(75.5)\end{array}$ & $75(25.3)$ & $404(54.2)$ & $\begin{array}{l}304 \\
(75.7)\end{array}$ & $\begin{array}{l}111 \\
(27.5)\end{array}$ \\
\hline$\geq 65$ years & $\begin{array}{l}341 \\
(49.9) \star \star\end{array}$ & $\begin{array}{l}340 \\
(80.8)^{\star \star}\end{array}$ & $\begin{array}{l}106 \\
(25.2)\end{array}$ & $\begin{array}{l}575 \\
(64.6)^{\star \star}\end{array}$ & $\begin{array}{l}458 \\
(80.2) \star \star\end{array}$ & $\begin{array}{l}189 \\
(32.9)\end{array}$ \\
\hline \multicolumn{7}{|l|}{ Ethnicity } \\
\hline Han & 709 (42.7) & $\begin{array}{l}674 \\
(79.7)\end{array}$ & $\begin{array}{l}226 \\
(25.7)\end{array}$ & $\begin{array}{l}1287 \\
(53.2) \star\end{array}$ & $\begin{array}{l}981 \\
(76.2)\end{array}$ & $\begin{array}{l}394 \\
(31.2)^{\star}\end{array}$ \\
\hline Minority & $47(35.9)$ & $\begin{array}{l}43 \\
(64.3)^{\star}\end{array}$ & $14(27.5)$ & $52(49.5)$ & $\begin{array}{l}33 \\
(63.5)^{\star}\end{array}$ & $16(30.0)$ \\
\hline \multicolumn{7}{|l|}{$\begin{array}{l}\text { Level of } \\
\text { education }\end{array}$} \\
\hline Illiterate & $280(40.1)$ & $\begin{array}{l}255 \\
(75.3)\end{array}$ & $96(24.0)$ & $561(49.0)$ & $\begin{array}{l}427 \\
(76.1)\end{array}$ & $\begin{array}{l}129 \\
(23.0)\end{array}$ \\
\hline $\begin{array}{l}\text { Primary (grade } \\
1-6 \text { ) or higher }\end{array}$ & $476(44.7)^{\star}$ & $\begin{array}{l}462 \\
(75.0)\end{array}$ & $\begin{array}{l}144 \\
(29.1)^{\star}\end{array}$ & $\begin{array}{l}778 \\
(56.5) \star \star\end{array}$ & $\begin{array}{l}587 \\
(75.4)\end{array}$ & $\begin{array}{l}281 \\
(36.1) \star \star\end{array}$ \\
\hline
\end{tabular}

$\star P<0.05, * * P<0.01$ 


\begin{tabular}{|c|c|c|c|c|c|c|}
\hline \multirow[t]{2}{*}{ Characteristic } & \multicolumn{3}{|l|}{2009} & \multicolumn{3}{|l|}{2016} \\
\hline & $\begin{array}{l}\text { Awareness } \\
\text { of } \\
\text { condition } \\
\mathrm{n}(\%)\end{array}$ & $\begin{array}{l}\text { Under } \\
\text { treatment } \\
\mathrm{n}(\%)\end{array}$ & $\begin{array}{l}\text { Condition } \\
\text { controlled } \\
\mathrm{n}(\%)\end{array}$ & $\begin{array}{l}\text { Awareness } \\
\text { of } \\
\text { condition } \\
\mathrm{n}(\%)\end{array}$ & $\begin{array}{l}\text { Under } \\
\text { treatment } \\
\mathrm{n}(\%)\end{array}$ & $\begin{array}{l}\text { Condition } \\
\text { controlled } \\
\mathrm{n}(\%)\end{array}$ \\
\hline Low & $372(43.2)$ & $\begin{array}{l}341 \\
(75.0)\end{array}$ & $\begin{array}{l}125 \\
(27.1)\end{array}$ & $\begin{array}{l}743 \\
(52.8)^{\star *}\end{array}$ & $\begin{array}{l}427 \\
(76.1)\end{array}$ & $\begin{array}{l}194 \\
(26.1)\end{array}$ \\
\hline High & $384(41.3)$ & $\begin{array}{l}376 \\
(75.5)\end{array}$ & $\begin{array}{l}115 \\
(24.7)\end{array}$ & $\begin{array}{l}596 \\
(53.4)^{\star \star}\end{array}$ & $\begin{array}{l}587 \\
(75.4)\end{array}$ & $\begin{array}{l}216 \\
(36.2) \star \star\end{array}$ \\
\hline All & $756(42.2)$ & $\begin{array}{l}717 \\
(75.1)\end{array}$ & $\begin{array}{l}240 \\
(25.8)\end{array}$ & $\begin{array}{l}1339 \\
(53.1)^{\star \star \star}\end{array}$ & $\begin{array}{l}1014 \\
(75.7)\end{array}$ & $\begin{array}{l}410 \\
(30.6)^{*}\end{array}$ \\
\hline
\end{tabular}

\section{Discussion}

The findings indicated high rates in the prevalence of pre-hypertension and hypertension, relatively low levels in hypertension awareness, treatment, and control, and a total increase in the hypertension prevalence, awareness, and control in rural Southwestern China. However, the trend in the treatment of hypertension did not differ over the 7 years studied. The findings also indicated that ethnicity and individual SES have significant relationships with actual hypertension prevalence, awareness, and control, as well as the temporal trends in the hypertension prevalence, awareness, and control.

In the study, the prevalence of pre-hypertension (50.0\%) in Yunnan Province was greater than that observed in central China (27.4\%) [15] or Iran (31.6\%) [16]. The hypertension prevalence (39.5\%) in Yunnan Province was also higher than in other parts of China (24.7\%) [17] and other Asian countries, including Myanmar (34.2\%) [10], Vietnam (18.4\%) [18], and other low- and middle-income countries (32.3\%) [19]. The prevalence of pre-hypertension and hypertension was relatively high in rural Yunnan Province across the study period. The study did not show a growth in the prevalence of pre-hypertension over the 7 years studied. However, it revealed a substantially increasing trend in hypertension prevalence and indicated that hypertension is a chief and increasing public health issue in the regions under study. The findings suggested that more effective interventions are needed to avoid and control hypertension. Encouragingly, the hypertension awareness, treatment, and control rates $(53.1 \%, 75.7 \%$, and $30.6 \%$, respectively) in 2016 were higher than those found in a national study of China (36.0\%, 22.9\%, and 5.7\%) [20], indicating that hypertension health education programs and improving access to healthcare have helped achieve progress in rural Southwestern China.

The study also revealed gender variances in the prevalence of pre-hypertension, in hypertension awareness and control, as well as in trends in the hypertension prevalence. The hypertension prevalence, 
awareness, and control increased markedly both men and women in rural Southwestern China over the seven years studied, similar to the results of rural areas conducted in Myanmar [10]. One possible reason for the variance in the prevalence of pre-hypertension between men and women is that men meet metabolic hazard opportunities for pre-hypertension more commonly than women. Although previous Chinese studies demonstrated that males had a higher hypertension prevalence than females [15, 17], our study showed no relationship between gender and the hypertension prevalence. Greater awareness and control rates in females were found in the study, which can be explained by previous research indicating that females report more use of health services than males [21]. Thus, more screening and treatment projects and opportunities for males are desired.

The study also showed ethnic differences in temporal trends in hypertension prevalence, and hypertension awareness, treatment, and control in rural Southwestern China. Consistent with another study conducted in Europe [22], ethnic variation concerning hypertension was found in the study. In 2009, the Han people's hypertension prevalence was found to be equivalent with that in ethnic minority groups. However, the Han people had higher prevalence of hypertension than ethnic minority populations over the seven years studied. One of the reasons might be that ethnic minorities have healthier lifestyles, such as plain food and more activities [23]. In both 2009 and 2016, the treatment rate of hypertension in ethnic minority populations was significantly lower than which in the Han people, which may be attributed to the economically disadvantaged status of the ethnic minority population [24]. Furthermore, only the Han majority population improved the rates in hypertension awareness and control. Thus, specific efforts must be taken in the ethnic minority groups to advance the awareness, treatment, and control of hypertension as well as to improve their economic status and their access to medical services.

In the study, we discovered that the level of education impacted the hypertension prevalence, awareness, and control. In 2016, the hypertension prevalence rate was higher in illiterate group than in their counterparts. This result was inconsistent with that from a prior study [25], which reported that people who have higher education position had a higher hypertension prevalence. Over the seven years we studied, the hypertension prevalence markedly increased in less educated people. However, there was no remarkable change in the increase of awareness, treatment, and control between different education levels groups. In particular, the study showed stable treatment rates of hypertension between the two survey years, suggesting that the treatment of hypertension had entered a bottleneck stage in the study region, and novel effective measures should be taken to continue to improve the treatment rate. In both 2009 and 2016, higher rates in awareness and control were found in more educated people than less educated participants. Although the treatment of hypertension did not differ in groups with diverse education level, the control of hypertension was significantly lower in illiterate groups than in educated groups. The specific reasons need further study.

In this study, the hypertension prevalence in the low-income population significantly increased over the 7 years studied. Low-income individuals were more possible to experience hypertension than their higherincome ones. This finding aligned with those in previous studies [12, 26], but it was inconsistent with other studies $[25,27]$. Although there was a significant increase in awareness between different income 
groups over the 7 years studied, it only appeared in the high-income group for control. Encouragingly, the study revealed a similar treatment rate of hypertension between low-income participants and their higherincome counterparts both in 2009 and in 2016. Although the low-income participants had equivalent awareness and treatment of hypertension as their higher-income counterparts, the rate of control was dramatically lower in the low-income participants than their counterparts over the 7 years studied. The reasons might be low-income people use incorrect treatment methods or do not adhere to their treatment for a long time [28]. The findings underline an urgent need to improve the control of hypertension for the low-income population.

There were some limitations in the study. First, as the data were collected using a cross-sectional design, we were unable to determine causal relationships. Second, the trends in prevalence, awareness, treatment, and control of hypertension were analyzed based on a seven years study period, which is a relatively short-range time period; to determine whether the trends will persist over a longer time frame, more data will be needed.

\section{Conclusions}

In conclusion, the study displayed that the prevalence of hypertension as well as hypertension awareness and control significantly increased in rural Southwestern China from 2009 to 2016, with ethnicity and individual SES having clear associations with the trends in prevalence, awareness, and control of hypertension. However, the hypertension treatment did not differ over the 7 years studied. The findings indicated that the policymakers should increase levels of awareness and control to promote the hypertension prevention and management, as well as employ effective interventions that consider socioeconomic disparities.

\section{Abbreviations}

AHA: American Heart Association; BP: Blood pressure; CVDs: Cardiovascular diseases; DBP: Diastolic blood pressure; GDP: Gross domestic product; NCDs: Non-communicable diseases; PPS: Probability proportional to size; SBP: Systolic blood pressure; SES: Socioeconomic status

\section{Declarations}

\section{Acknowledgements}

Not applicable.

\section{Authors' contributions}

LC conceptualized the research idea and revised the manuscript. LMF participated in the study and drafted the manuscript. FW, MZ, and WLC collected the data. All authors read and approved the final manuscript. 


\section{Funding}

The present study was supported by grant from the National Natural Science Fund of China (Grant numbers: 72064026), Program for Innovative Research Team of Yunnan Province (2019(6)), and Program for Innovative Research Team (in Science and Technology) in University of Yunnan Province ((2018)134). The funders had no role in study design, decision to publish, or preparation of the manuscript.

\section{Availability of data and materials}

The datasets used and analyzed during our study are available from the corresponding author on reasonable request.

\section{Ethics approval and consent to participate}

This study was approved by the Ethics Committee at Kunming Medical University prior to the start of the research. Written informed consent was obtained from all participants in our study, and the Ethics Committee at Kunming Medical University approved this consent procedure.

\section{Consent for publication}

Not applicable.

\section{Competing interests}

The authors declare that they have no competing interests.

\section{Author details}

${ }^{1}$ School of Public Health, Kunming Medical University, 1168 Yu Hua Street Chun Rong Road, Cheng Gong New City, Kunming 650500, China. ${ }^{2}$ Department of Science and Technology, Kunming Medical University, 1168 Yu Hua Street Chun Rong Road, Cheng Gong New City, Kunming 650500, China.

\section{References}

1. Go AS, Mozaffarian D, Roger VL, Benjamin EJ, Berry JD, Borden WB, Bravata DM, Dai S, Ford ES, Fox CS, Franco S, Fullerton HJ, Gillespie C, Hailpern SM, Heit JA, Howard VJ, Huffman MD, Kissela BM, Kittner SJ, Lackland DT, Lichtman JH, Lisabeth LD, Magid D, Marcus GM, Marelli A, Matchar DB, McGuire DK, Mohler ER, Moy CS, Mussolino ME, Nichol G, Paynter NP, Schreiner PJ, Sorlie PD, Stein J, Turan TN, Virani SS, Wong ND, Woo D, Turner MB. Executive summary: heart disease and stroke statistics-2013 update: a report from the American Heart Association. Circulation. 2013;127:143-52.

2. Worldwide trends in blood pressure from 1975 to 2015: a pooled analysis of 1479 population-based measurement studies with 19.1 million participants. Lancet. 2017;389:37-55. 
3. Wang J, Sun W, Wells GA, Li Z, Li T, Wu J, Zhang Y, Liu Y, Li L, Yu Y, Liu Y, Qi C, Lu Y, Liu N, Yan Y, Liu L, Hui G, Liu B. Differences in prevalence of hypertension and associated risk factors in urban and rural residents of the northeastern region of the People's Republic of China: A cross-sectional study. PLoS One. 2018;13:e195340.

4. Guo X, Zou L, Zhang X, Li J, Zheng L, Sun Z, Hu J, Wong ND, Sun Y. Prehypertension: a meta-analysis of the epidemiology, risk factors, and predictors of progression. Tex Heart Inst J. 2011;38:643-52.

5. Kim SJ, Lee J, Nam CM, Jee SH, Park IS, Lee KJ, Lee SY. Progression rate from new-onset prehypertension to hypertension in Korean adults. Circ. J. 2011;75:135-40.

6. Nwankwo T, Yoon SS, Burt V, Gu Q. Hypertension among adults in the United States: National Health and Nutrition Examination Survey, 2011-2012. NCHS Data Brief. 2013:1-8.

7. Abdul-Razak S, Daher AM, Ramli AS, Ariffın F, Mazapuspavina MY, Ambigga KS, Miskan M, AbdulHamid H, Mat-Nasir N, Nor-Ashikin MN, Ng KK, Nawawi H, Yusoff K. Prevalence, awareness, treatment, control and socio demographic determinants of hypertension in Malaysian adults. BMC Public Health. 2016;16:351.

8. Zhao L, Sun W, Wang J, Wu J, Zhang Y, Liu Y, Liu B. Differences in the treatment and control of hypertension in urban and rural residents of the northeastern region of the People's Republic of China: a cross-sectional study. Clin. Exp. Hypertens. 2019;41:366-72.

9. Wang Y, Peng X, Nie X, Chen L, Weldon R, Zhang W, Xiao D, Cai J. Burden of hypertension in China over the past decades: Systematic analysis of prevalence, treatment and control of hypertension. Eur. J. Prev. Cardiol. 2016;23:792-800.

10. Htet AS, Bjertness MB, Oo WM, Kjøllesdal MK, Sherpa LY, Zaw KK, Ko K, Stigum H, Meyer HE, Bjertness E. Changes in prevalence, awareness, treatment and control of hypertension from 2004 to 2014 among 25-74-year-old citizens in the Yangon Region, Myanmar. BMC Public Health. 2017; $17: 847$.

11. Zhang R, Deng R, Shen P, Fan M, Leng B, Zhou Y, Cui Y, Li G. Prehypertension and socioeconomic status: A cross-sectional study in Chongqing, China. Clin. Exp. Hypertens. 2017;39:774-80.

12. Leng B, Jin Y, Li G, Chen L, Jin N. Socioeconomic status and hypertension: a meta-analysis. J. Hypertens. 2015;33:221-9.

13. Pickering TG, Hall JE, Appel LJ, Falkner BE, Graves J, Hill MN, Jones DW, Kurtz T, Sheps SG, Roccella EJ. Recommendations for blood pressure measurement in humans and experimental animals: Part 1: blood pressure measurement in humans: a statement for professionals from the Subcommittee of Professional and Public Education of the American Heart Association Council on High Blood Pressure Research. Hypertension. 2005;45:142-61.

14. James PA, Oparil S, Carter BL, Cushman WC, Dennison-Himmelfarb C, Handler J, Lackland DT, LeFevre ML, MacKenzie TD, Ogedegbe O, Smith SJ, Svetkey LP, Taler SJ, Townsend RR, Wright JJ, Narva AS, Ortiz E. 2014 evidence-based guideline for the management of high blood pressure in adults: report from the panel members appointed to the Eighth Joint National Committee (JNC 8). JAMA. 2014;311:507-20. 
15. Chen C, Yuan Z. Prevalence and risk factors for prehypertension and hypertension among adults in Central China from 2000-2011. Clin. Exp. Hypertens. 2018;40:734-43.

16. Afsargharehbagh R, Rezaie-Keikhaie K, Rafiemanesh H, Balouchi A, Bouya S, Dehghan B. Hypertension and Pre-Hypertension Among Iranian Adults Population: a Meta-Analysis of Prevalence, Awareness, Treatment, and Control. Curr. Hypertens. Rep. 2019;21:27.

17. Wu J, Li T, Song X, Sun W, Zhang Y, Liu Y, Li L, Yu Y, Liu Y, Qi C, Liu B. Prevalence and distribution of hypertension and related risk factors in Jilin Province, China 2015: a cross-sectional study. BMJ Open. 2018;8:e20126.

18. Meiqari L, Essink D, Wright P, Scheele F. Prevalence of Hypertension in Vietnam: A Systematic Review and Meta-Analysis. Asia Pac J Public Health. 2019;31:101-12.

19. Sarki AM, Nduka CU, Stranges S, Kandala NB, Uthman OA. Prevalence of Hypertension in Low- and Middle-Income Countries: A Systematic Review and Meta-Analysis. Medicine (Baltimore). 2015;94:e1959.

20. Lu J, Lu Y, Wang X, Li X, Linderman GC, Wu C, Cheng X, Mu L, Zhang H, Liu J, Su M, Zhao H, Spatz ES, Spertus JA, Masoudi FA, Krumholz HM, Jiang L. Prevalence, awareness, treatment, and control of hypertension in China: data from 1.7 million adults in a population-based screening study (China PEACE Million Persons Project). Lancet. 2017;390:2549-58.

21. Vaidya V, Partha G, Karmakar M. Gender differences in utilization of preventive care services in the United States. J Womens Health (Larchmt). 2012;21:140-5.

22. Modesti PA, Reboldi G, Cappuccio FP, Agyemang C, Remuzzi G, Rapi S, Perruolo E, Parati G. Panethnic Differences in Blood Pressure in Europe: A Systematic Review and Meta-Analysis. PLoS One. 2016;11:e147601.

23. Ruixing Y, Qiming F, Dezhai Y, Shuquan L, Weixiong L, Shangling P, Hai W, Yongzhong Y, Feng H, Shuming Q. Comparison of demography, diet, lifestyle, and serum lipid levels between the Guangxi Bai Ku Yao and Han populations. J. Lipid Res. 2007;48:2673-81.

24. Cai L, Wang XM, Fan LM, Shen JR, Liu YN, Golden AR. Socioeconomic variations in chronic obstructive pulmonary disease prevalence, diagnosis, and treatment in rural Southwest China. BMC Public Health. 2020;20:536.

25. Hasan M, Sutradhar I, Akter T, Das GR, Joshi H, Haider MR, Sarker M. Prevalence and determinants of hypertension among adult population in Nepal: Data from Nepal Demographic and Health Survey 2016. PLoS One. 2018;13:e198028.

26. Wang Q, Shen JJ, Frakes K. Limited contribution of health behaviours to expanding income-related chronic disease disparities based on a nationwide cross-sectional study in China. Sci Rep. 2018;8:12485.

27. Cai L, Dong J, Cui WL, You DY, Golden AR. Socioeconomic differences in prevalence, awareness, control and self-management of hypertension among four minority ethnic groups, Na Xi, Li Shu, Dai and Jing Po, in rural southwest China. J. Hum. Hypertens. 2017;31:388-94. 
28. Kunz M, Lauder L, Ewen S, Bohm M, Mahfoud F. The Current Status of Devices for the Treatment of Resistant Hypertension. Am. J. Hypertens. 2020;33:10-8. 